Asian-Australasian Journal of

Food Safety and Security

ISSN 2523-1073 (Print) 2523-2983 (Online)

www.ebupress.com/journal/aajfss

\title{
Article \\ Prevalence of Salmonella in dressed and cooked broiler meat of different grocery shops, hotels and restaurants in Gazipur and Dhaka city of Bangladesh
}

\author{
A.K.M. Ziaul Haque ${ }^{1 *}$, S. M. Lutful Kabir ${ }^{2}$, Ayesha Siddiqua ${ }^{3}$ and A.Z.M. Iftikhar Hussain ${ }^{1}$ \\ ${ }^{1}$ Department of Public Health, Atish Dipankar University of Science \& Technology, Uttara, Dhaka, Bangladesh \\ ${ }^{2}$ Department of Microbiology and Hygiene, Bangladesh Agricultural University, Mymensingh-2202, \\ Bangladesh \\ ${ }^{3}$ Department of Anatomy and Histology, Gonoshasthaya Samaj Vittik Medical College, Savar, Bangladesh
}

*Corresponding author: A.K.M. Ziaul Haque, Department of Public Health, Atish Dipankar University of Science \& Technology, Uttara, DHAKA, Bangladesh. Phone: +8801777793074; E-mail: vetzia.2004.bd@gmail.com

Received: 10 October 2018/Accepted: 31 October 2018/ Published: 29 November 2018

\begin{abstract}
The study was conducted to find out the prevalence of Salmonella in dressed and cooked broiler meat in different shops and restaurants in Gazipur and Dhaka city including the sanitary quality. A total of 80 samples of dressed boiler, 88 cooked samples from road side fast food shops and small hotels, and 104 cooked samples from recognized fast food shops and restaurants were subjected to bacteriological isolation and identification. Highest number of Salmonella spp. were $42.5 \%$ in road side shops and $16.25 \%$ found in super market for dressed meat. Thigh muscle was more prevalent to breast muscle in both market types for dressed muscle. A total of 31 thigh muscles were positive for road side shop and 23 for super market where 26 and 19 breast muscle were positive for road side shop and super market respectively. Among the cooked meat or fried chicken incidence of Salmonella spp. were $23.86 \%$ in road side shops and $11.54 \%$ found in recognized shops. In case of both market source thigh muscle was highly prevalent in comparison to breast muscle. For cooked meat, a total of 19 thigh muscles were positive for road side fast food shops and small hotels, and 12 for recognized fast food shops and restaurants where 15 and 8 breast muscle were positive for road side fast food shops and recognized fast food shops respectively. Our results highlighted the need of implementing strict hygiene and sanitation standards to reduce the incidence of Salmonella. The prevalence of Salmonella in poultry products can be reduced effectively by identifying and eliminating the sources and contamination sites during slaughter and processing of poultry.
\end{abstract}

Keywords: broiler; Salmonella; meat; food safety

\section{Introduction}

Now a day's salmonellosis is a common and serious problem in the poultry industry of the world especially in the developing country including Bangladesh. Poultry industry is a rising profitable sector in Bangladesh. There has been tremendous development of this sector over the recent years in this country (Islam et al., 2018). However, the advancement of poultry industry is seriously hampered due to the outbreak of various infectious and non-infectious diseases. Among the bacterial diseases, salmonellosis caused by the genus Salmonella is of major problems in the poultry industry in Bangladesh (Sarker et al., 2015). It causes a variety of acute and chronic diseases of poultry in Bangladesh. The disease may occur in chicken, duck, pigeon, quail, insects and rodent and other animals and birds. More than 2,300 serotypes of all the isolated Salmonella, 10\% of these have been isolated from poultry (Hyeon et al., 2011).

Salmonella is one of the most important pathogens responsible for human food poisoning in the developed \& also in the developing countries and chicken products are widely acknowledged to be significant reservoir for 
salmonella. They have frequently been incriminated as a source of salmonella contamination and consequently thought to be major sources of the pathogen in humans (Hasan et al., 2018). Furthermore, one of the most common causes of Salmonella infection reported in humans has been through the handling of raw poultry carcasses and products, together with the consumption of undercooked poultry meat \& poultry products.

It is one of the most frequently reported food-borne diseases worldwide as well as in Bangladesh. The US Centers for Disease Control and Prevention (CDC) estimate 1.4 million cases, 16430 hospitalizations, and 582 deaths in the United States of America annually (Mead et al., 1999).

Salmonella spp. is potentially responsible for various pathogenic processes in man and animal including poultry. It can cause diarrhea, vomition, fever, abdominal cramps in human. Sometimes severe diarrhea requires medical interventions such as intravenous fluid therapy. In cases, where bacteria enter into the bloodstream, symptoms include high fever, malaise, pain in the thorax and abdomen, chills and anorexia (Bell, 2002). Antibiotics are extensively used in poultry industry either as a growth promoter or to control infectious diseases (Sarker et al., 2018). Concern about antibiotic resistance and its transmission to human is important because these resistant bacteria may colonize in human gastrointestinal tract and may contribute resistance genes to human through Rfactor, conjugative plasmids or chromosomal elements as reviewed by (Kabir et al., 2010). Therefore, the disease causing microbes that have become resistant to antibiotic drug therapy are increasing public health importance. Undoubtedly the poultry slaughtered and dressed under Bangladesh conditions carry extremely high initial contamination loading from the point of slaughtering process to the point at which the consumers are offered the product.

Therefore the present study was undertaken in dressed broiler and cooked meat sold in different grocery shops, restaurants and fast food shops in Gazipur and Dhaka city to know the load of harmful Salmonella.

\section{Materials and Methods}

\subsection{Collection and transportation of samples}

A total of 80 dressed broilers and 104 cooked broiler meat samples were collected from different types of retail shops, road side restaurants and fast-food shops of Gazipur and Dhaka city of Bangladesh. After collection, immediately brought to Bacteriology Laboratory of the Department of Microbiology and Hygiene, Bangladesh Agricultural University, Mymensingh through maintaining cool chain using ice box.

\subsection{Bacterial culture media}

Solid and liquid culture media were used to isolate the bacteria. Blood agar, MSRV media, MacConkey agar (MC), Salmonella-Shigella agar (SS), Eosin Methylene Blue agar (EMB), BGA, Xylose-Lysine Deoxycholate agar (XLD), Tetrathionate and Mueller Hinton agar were used as solid culture media for this study. The liquid media used in the study were nutrient broth (NB), peptone broth, methyl-red and voges-proskauer broth (MRVP), indole, catalase, TSI, SPA and sugar media, $1 \%$ hippurate solution, 3.5\% ninhydrin solution, oxidase solution and sugar media.

\subsection{Isolation and identification of bacteria}

Pure culture of Salmonella spp. was obtained as per the methods described by Krieg et al. (1994). Briefly, 10 gm of samples were homogenized with $90 \mathrm{ml}$ of $0.1 \%$ peptone water and $50 \mu 1$ of homogenized sample was poured on to selective agar media and spread with glass spreader and incubated at $37^{\circ} \mathrm{C}$ for 24 hours. The colonies of primary cultures were repeatedly sub-cultured by streak plate method (Cheesbrough, 1985) until the pure cultures with homogenous colonies were appeared.

\section{Results and Discussion}

Dressed broiler from different categories shop and cooked meat from hotel and restaurant are used as a regular food by the majority of the Gazipur \& Dhaka city. Among the dressed broiler incidence of Salmonella spp. were 42.5\% (34 sample showed positive among 80 samples) in road side shops and 16.25\% (13 samples showed positive among 80 samples) found in super markets (Table 1). In case of dressed broiler meat prevalence of Salmonella are shown in Table 2.

Table 1. Salmonella isolation from dressed broiler collected from different shops $(\mathrm{N}=80)$.

\begin{tabular}{lll}
\hline Shop location & No. of positive sample & Percentage (\%) \\
\hline Road side shops & 34 & 42.5 \\
Super markets & 13 & 16.25 \\
\hline
\end{tabular}


Table 2. Prevalence of Salmonella in dressed broiler meat $(\mathrm{N}=80)$.

\begin{tabular}{llc}
\hline \multirow{2}{*}{ Source } & \multicolumn{1}{c}{ Number (\%) of positive sample } \\
\cline { 2 - 3 } & Breast muscle & Thigh muscle \\
\hline Road side shops & $26(32.5)$ & $31(38.75)$ \\
Super markets & $19(23.75)$ & $23(28.75)$ \\
\hline
\end{tabular}

Among the cooked meat or fried chicken incidence of Salmonella spp. were $23.86 \%$ (21 sample showed positive among 88 samples) in road side shops and 11.54\% (12 samples showed positive among 104 samples) found in super markets (Table 3).

Table 3. Salmonella isolation from cooked meat collected from different shops.

\begin{tabular}{lll}
\hline Shop location & No. of positive sample & Percentage $(\%)$ \\
\hline Road side fast food shops and small hotels $(\mathrm{N}=88)$ & 21 & 23.86 \\
Recognized fast food shops and restaurants $(\mathrm{N}=104)$ & 12 & 11.54 \\
\hline
\end{tabular}

In case of thigh muscle highest number of positive sample was found for road side fast food shops and small hotels followed by breast muscle. Details are shown in Table 4.

Table 4. Prevalence of Salmonella in cooked broiler meat.

\begin{tabular}{lll}
\hline \multirow{2}{*}{ Source } & \multicolumn{2}{c}{ Number (\%) of positive sample } \\
\cline { 2 - 3 } & Breast muscle & Thigh muscle \\
\hline Road side fast food shops and small hotels $(\mathrm{N}=88)$ & $15(17.05)$ & $19(21.60)$ \\
Recognized fast food shops and restaurants $(\mathrm{N}=104)$ & $8(7.70)$ & $12(11.54)$ \\
\hline
\end{tabular}

Normally broilers are kept in cage in road side shop and dressed broilers are kept in deep fridge in the recognized super market. Some people buy from road side shop and some buy from super market and then taken to home for eat. On the other hand in hotel and restaurant or different recognized fast food shopping mall sold cooked meat or fried chicken as a regular food to peoples.

The prevalence of cooked meat was highest (23.86\%) in road side fast food shops and small hotels than recognized restaurants $(11.54 \%)$. So this type of dressed broiler or cooked meat has a great public health importance. It was clear that, these type shops have failed to protect against typhoid or gastrointestinal disorder, despite regular use of different types of modern machine.

Recent studies have demonstrated that peoples who are habituate in fast food are increasingly vulnerable to Salmonella contamination. Such problems arise even in developed countries. Poultry have a major role as vehicles of transmission in human cases of salmonellosis. An assessment of factors affecting the prevalence and growth of Salmonella on broiler chicken carcasses would be useful to risk managers in identifying the intervention strategies that would have the greatest impact on reducing human infections. Broiler chicken is the main type of chicken consumed as poultry in many countries. A large percentage of poultry is colonized by Salmonella during grow-out, and the skin and meat of carcasses are frequently contaminated by the pathogen during slaughter and processing ( $\mathrm{Li}$ et al., 2013). The people of studied area are more habituate in fast food. So, foodborne diseases are arises increasingly in this area due to Salmonella contamination in the fast food. The high degree of contamination of cooked meat in households poses a health hazard to consumers (Ahmed et al., 2009).

Broiler dressing procedure, waste products disposal, disinfection of different materials which is used for dressing purposes or cooked purposes with different scientific method, pasteurization of food, and by a general enhancement of hygiene, that foodborne pathogenic Salmonella and their diseases finally controlled to an acceptable level in most countries (Bae et al., 2013). Foodborne diseases should not be seen as an independent part of the infectious disease cycle, but as a vehicle for their transmission (Anderson and Ziprin, 2001).

In this research project present study Salmonella were found in the poultry meat, which was supported by Islam et al. (2018), Hossain et al. (2015), Malmuthuge et al. (2012), Sudershan et al. (2012), Torok et al. (2011), Ahmed et al. (2009) and Zhao et al. (2001). Several selective culture media were used simultaneously in this study to culture the organism. The media used in this study were selected considering the experience of the past 
researchers worked in various fields relevant to the present study by Kabir et al. (2014). The colony morphology of Salmonella spp. was similar to that of Sarker et al. (2009).

However, the results of this study show clearly that dressed broiler and cooked broiler meat sold in different shops or restaurants or fast food shops of Gazipur \& Dhaka city that were examined contained high counts of Salmonella and contains a great public health importance.

\section{Conclusions}

It may be concluded that all samples of dressed broiler and cooked meat sold in different shops, restaurants and fast food shops in Gazipur and Dhaka city that were examined contained load of harmful bacteria Salmonella. More sanitization and good cooking procedure should be adopted to avoid the risk of spreading foodborne Salmonella through these types of products sold in different shops, restaurants and fast food shops.

\section{Conflict of interest}

None to declare.

\section{References}

Ahmed AM, H Shimabukuro and T Shimamoto, 2009. Isolation and molecular characterization of multidrugresistant strains of E. coli and Salmonella from retail chicken meat in Japan. J. Food Sci., 74: 405-410.

Ahmed AM, H Shimabukuro and T Shimamoto, 2009. Isolation and molecular characterization of multidrugresistant strains of Escherichia coli and Salmonella from retail chicken meat in Japan. J. Food Sci., 74: 405.

Anderson RC and RL Ziprin, 2001. Bacteriology of Salmonella. Foodborne Disease Handbook. Vol. 1. Y. H. Hui, M. D. Pierson, and J. R. Gorham, ed. Marcel Dekker, Inc., New York, NY. pp. 247-263.

Bae DH, HK Dessie, HJ Baek, SG Kim, HS Lee and YJ Lee, 2013. Prevalence and characteristics of Salmonella spp. isolated from poultry slaughterhouses in Korea. J. Vet. Med. Sci., 13:13-93.

Bell C, 2002. Foodborne pathogens: Hazards, risk analysis and control. Woodhead Publishing and CRC Press 307-335.

Cheesbrough M, 1985. Medical laboratory manual for tropical countries. English Language Book Society, London 1: 400-480.

Hasan M, SML Kabir, T Rahman and YA Sarker, 2018. Bacteriological quality assessment of buffalo meat collected from different districts of Bangladesh with particular emphasis on the molecular detection and antimicrobial resistance of the isolated Salmonella species. Asian Australas. J. Food Saf. Secur., 2: 12-20.

Hossain M, N Hoda, MJ Hossen, MM Hassan, SME Rahman and SML Kabir, 2015. Assessment of bacterial load of poultry meat used at dining hall of Bangladesh Agricultural University campus. Asian J. Med. Biol. Res., 1: 9-16.

Hyeon JY, JW Chon, JG Hwang, HS Kwak, MS Kim, SK Kim, IS Choi, CS Song, C Park and KH Seo, 2011. Prevalence, antibiotic resistance and molecular characterization of Salmonella serovars in retail meat products. J. Food Prot., 74: 161-166.

Islam K, SML Kabir, AKMZ Haque, YA Sarker and MH Sikder, 2018. Molecular detection and characterization of Escherichia coli, Salmonella spp. and Campylobacter spp. isolated from broiler meat in Jamalpur, Tangail, Netrokona and Kishoreganj districts of Bangladesh. African J. Microbiol. Res., 12: 761770.

Kabir SML, 2010. Avian colibacillosis and salmonellosis: A closer look at epidemiology, pathogenesis, diagnosis, control and public health concerns. Int. J. Environ. Res. Public Health, 7: 89-114.

Kabir SML, MH Sumon, MM Amin and S Yamasaki, 2014. Isolation, identification and antimicrobial resistance patterns of Campylobacter species from broiler meat sold at KR Market of Bangladesh Agricultural University Campus, Mymensingh. J. Agric. Food Technol., 4: 15-21.

Krieg NR, JG Holt, PHA Sneath, JT Staley and ST Williams, 1994. Bergey's Manual of Determinative Bacteriology, Williams \& Wilkins, Baltimore, Md, USA, 9th edition.

Li R, J Lai, Y Wang, S Liu, Y Li, K Liu, J Shen and C Wu, 2013. Prevalence and characterization of Salmonella species isolated from pigs, ducks and chickens in Sichuan Province, China. Int. J. Food. Microbiol., 15:1418.

Malmuthuge N, M Li ,Y Chen, P Fries, PJ Griebel, B Baurhoo, X Zhao and LL Guan, 2012. Distinct commensal bacteria associated with ingests and mucosal epithelium in the gastrointestinal tracts of calves and chickens. FEMS Microbiology Ecology, 79: 337-347.

Mead P, L Slutsker, VLF Dietz, JS McCaig, C Bresee, C Shapiro, PM Griffin, and RV Tauxe, 1999. Foodrelated illness and death in the United States. Emerg. Infect. Diseases, 5: 607-625. 
Sarker SK, MB Rahman, M Rahman, MFR Khan, MSI Akand and MS Rahman, 2009. Seroprevalence study, isolation and identification of Salmonella in chickens selected model breeder poultry farms of Bangladesh. International Journal of Biological Research, 2: 25-29.

Sarker YA, AH Miah, N Sharif, MH Himel, S Islam, RC Ray, TK Paul, MT Islam and MH Sikder, 2015. A retrospective study of common diseases at Veterinary Teaching Hospital, Bangladesh Agricultural University, Mymensingh. Bangl. J. Vet. Med., 13: 55-61.

Sarker YA, MM Hasan, TK Paul, SZ Rashid, MN Alam and MH Sikder, 2018. Screening of antibiotic residues in chicken meat in Bangladesh by thin layer chromatography. J. Adv. Vet. Anim. Res., 5: 140-145.

Sudershan RV, R Naveen Kumar, L Kashinath, V Bhaskar and K Polasa, 2012. Microbiological hazard identification and exposure assessment of poultry products sold in various localities of Hyderabad, India. Scientific World Journal, 12: 736-740.

Torok VA, RJ Hughes, LL Mikkelsen, R Perez-Maldonado, K Balding, R MacAlpine, NJ Percy and K OphelKeller, 2011. Identification and characterization of potential performance-related gut microbiotas in broiler chickens across various feeding trials. Appl. Environ. Microbiol., 77: 5868-5878.

Zhao C, B Ge, J De-Villena, R Sudler, E Yeh, S Zhao and J Meng, 2001. Prevalence of Campylobacter spp., E. coli, and Salmonella serovars in retail chicken, turkey, pork, and beef from the Greater Washington, DC, area. Appl. Environ. Microbiol., 67: 5431-5436. 